\title{
The Sustainable Urban Alternatives House in Flint, Michigan
}

RICHARD HILL-ROWLEY ${ }^{1^{*}}$, GARRY GREEN ${ }^{1}$

Volume 2, Fall 2014

http://dx.doi.org/10.3998/mjs.12333712.0002.009

${ }^{1}$ Department of Earth and Resource Science, University of Michigan-Flint,

303 E. Kearsley Street Flint, MI 48502

*Corresponding author: Richard Hill-Rowley, rhr@umflint.edu

\section{ABSTRACT}

The University of Michigan-Flint (UM-Flint) and the Genesee County Land Bank (Land Bank) partnered to establish the Urban Alternatives House (UAH) at 924 Eddy Street in Flint's Central Park Neighborhood. It is home to two incomequalified, two-bedroom residential units and a classroom space for UM-Flint. The UAH location allows students at UM-Flint to walk to class.

The renovated house maximizes energy efficiency and introduces sustainable, innovative ways to manage energy and water use. Specific features include ground source heat pumps (sometimes called a geothermal system) for heating and cooling, solar panels, additional insulation to create a tight house envelope, and on-demand water heating. A food garden on the adjacent lot encourages more active and healthy living. The food garden is supported by a rainwater collection system, and stormwater is managed on site by two rain gardens. All of the features at the UAH provide a learning tool for the UM-Flint, the Land Bank, and the Flint community. The UAH is certified Platinum in the Leadership in Energy and Environmental Design (LEED) for Homes rating system and contributes to the sustainability of a walkable urban neighborhood.

\section{Introduction}

Sustainability has always been an important component of the Environmental Science and Planning degree program in the Department of Earth and Resource Sci- 
ence (ERS) at the University of Michigan-Flint (UM-Flint). But we needed a more explicit focus on urban issues in Flint, which lost $55 \%$ of its manufacturing jobs between 1995 and 2005 (Friedhoff and Wial 2006). These jobs were not replaced and the subsequent economic downturn led to a significant loss of population, $(27 \%$ decline between 1990 and 2010), abandoned houses, and neighborhood decline (U.S. Census Bureau 2014).

The Urban Alternatives House (UAH) was a response to this reality. In a community with an aging housing stock, rising energy prices, and a troubled economy, renovating a building close to campus for educational and residential purposes would support a neighborhood that was successfully struggling to maintain its viability. In addition, reducing energy costs can prevent foreclosures, and reusing existing housing stock promotes sustainability while maintaining the character and integrity of neighborhoods.

From an academic perspective, the project allowed UM-Flint to highlight a range of sustainability challenges (U.S. Environmental Protection Agency 2013). The UAH will be a laboratory for learning about energy efficiency, alternative energy systems, and sustainable lifestyles. Campuses across the United States (U.S.) are expanding programs in sustainability (Galbraith 2009), and the UAH idea became a catalyst for ERS to develop a new major in Energy and Sustainable Systems (ESS) to complement our existing planning program.

The project will also extend the reach of the University into a Flint neighborhood by providing an identifiable place for programs that support community-centered general education for our students and opportunities for area K-12 students to learn about the critical issues of sustainable living and climate change.

A key aspect in the revitalization of central Flint involves connecting the resources and activity of downtown Flint with those of the Flint Cultural Center. Because of its location in the Central Park Neighborhood, the UAH project will strengthen this link by adding students, faculty, staff, residents, and visitors to the flow from the neighborhood to the University and from there into downtown. The location is also midway between UM-Flint and Mott Community College, which creates potential for another link between the two institutions.

\section{Planning and Methods}

Partnership with the Genesee County Land Bank (Land Bank) was fundamental to the success of the UAH project. The Land Bank identified a building that was the 
right size and had a side lot for a geothermal heating, ventilation, and air conditioning (HVAC) installation and a food garden. It was located in the historic Carriage Town neighborhood, which is adjacent to downtown Flint where students could easily walk to class. With support from a planning grant provided by the Kresge Foundation and supplemental support from the C. S. Mott Foundation, a planning team from UM-Flint, the Land Bank, and the neighborhood began serious work on the project. The idea of a "green" renovation also captured the imagination of the community. At two public meetings, stakeholders, decision makers, students, and members of the public discussed concerns about the project and made suggestions for innovations that could be incorporated into the renovation. But in October 2010, the Carriage Town property was destroyed in an arson fire. Each institution assessed whether to proceed, and we were encouraged to do so by strong community support.

The Land Bank quickly identified another property from their inventory that met the project criteria and a new initiative was begun. The house is located at 924 Eddy Street in Central Park, a clearly defined neighborhood located directly east of the UM-Flint campus. Some funding from the original Kresge grant was still available for planning and this allowed us to retain an architect to develop new plans for the property. A graduate-level class in the University of Michigan-Ann Arbor's Urban Planning Program completed a comprehensive feasibility analysis for the project. This work involved additional public meetings, interviews with stakeholders, and a financial analysis (Barth et al. 2011). The Land Bank participated in this planning and implementation process with funding from the Neighborhood Stabilization Program (NSP2) (U.S. HUD 2014). Although NSP2 supported only residential development, it received approval to partner with UM-Flint after extensive consultation with the Michigan State Housing and Development Authority. The UM-Flint classroom space and part of the common areas were supported by The Rotary Club of Greater Flint, the C.S. Mott Foundation, and Consumers Energy. The Community Foundation of Greater Flint supported the solar installation.

Important elements of the original plan were incorporated into the new plans for Eddy Street: the geothermal HVAC system, the outdoor classroom area, the food garden, and the small kitchen designed for limited food preparation. Orientation of the Eddy Street house on a north/south axis made the addition of solar panels to the energy mix more feasible than at the original property. The Land Bank was the primary contracting agent for the building, and both partners decided to seek Leadership in Energy and Environmental Design (LEED) for Homes certification for the project (U.S. Green Building Council 2008). LEED is a green building certification 
program that recognizes best-in-class building strategies and practices. To receive LEED certification, building projects must satisfy prerequisites and earn points to achieve different levels of certification (U.S. Green Building Council 2014). The UAH is certified Platinum in the LEED for Homes rating system, which is the highest ranking possible.

\section{Implementation}

The renovation of the UAH project required gutting the interior of the house to remove asbestos and lead, as well as creating new floor plans for two income-qualified, two-bedroom residential units and a classroom space for UM-Flint and the Land Bank.

The following photo essay illustrates specific features of the implementation process. 


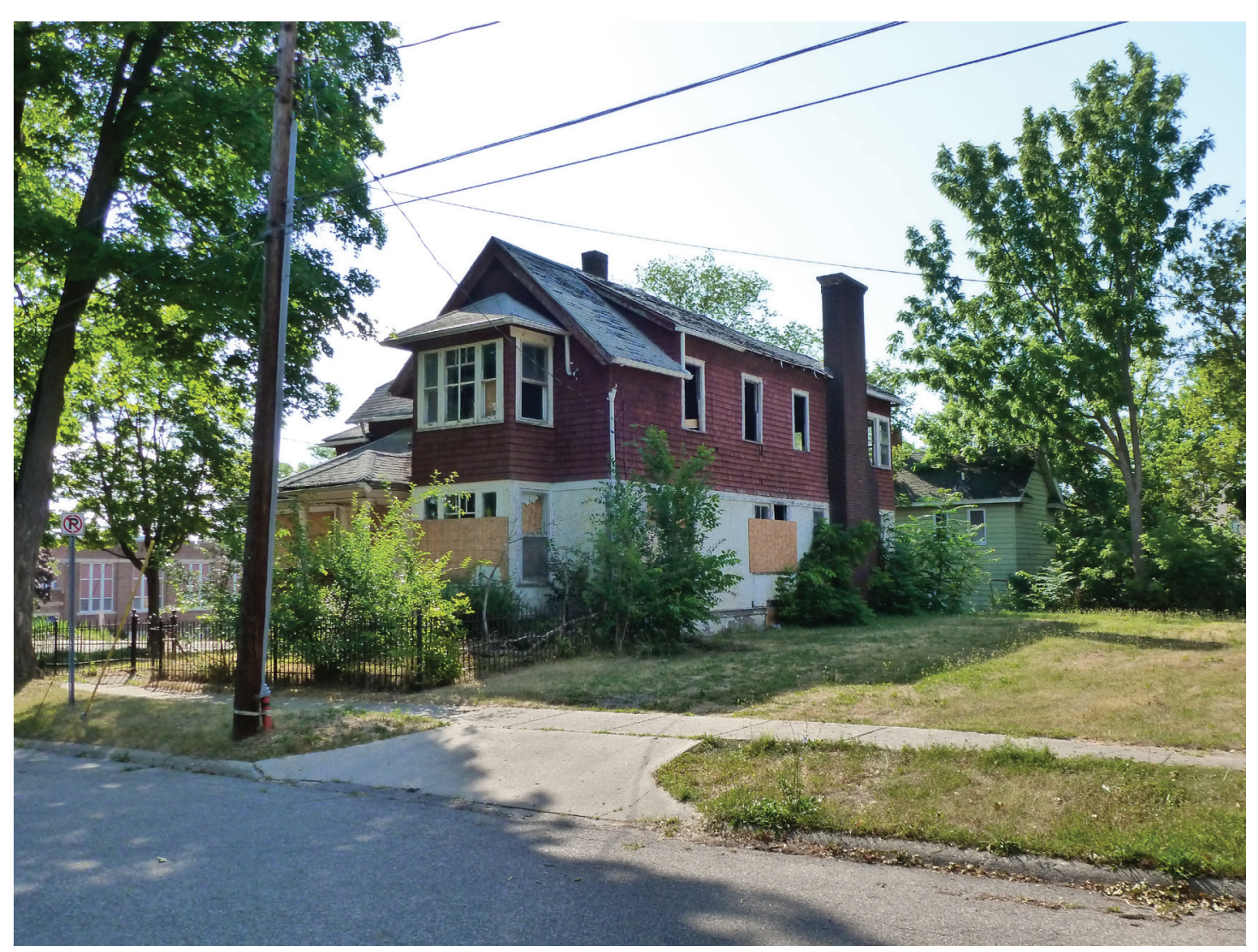

Figure 1. The property before renovation.

The Urban Alternatives House (UAH) at 924 Eddy Street in Flint was built in the 1920s. It was a distinguished property originally owned by the W.F. Stewart family whose company supplied automobile bodies to Buick and General Motors. It is located in the Central Park area of the city; a small, clearly defined neighborhood located directly east of the UM-Flint campus. Like many Flint neighborhoods, it has declined as automobile manufacturing relocated. But Central Park has a strategic location in relationship to community assets that is not present in other neighborhoods. The UAH also contributes to the area's stability as students walk to and from class, adding to its credentials as a walkable neighborhood, and provides a model for new residential renovation should demand for new housing emerge. 


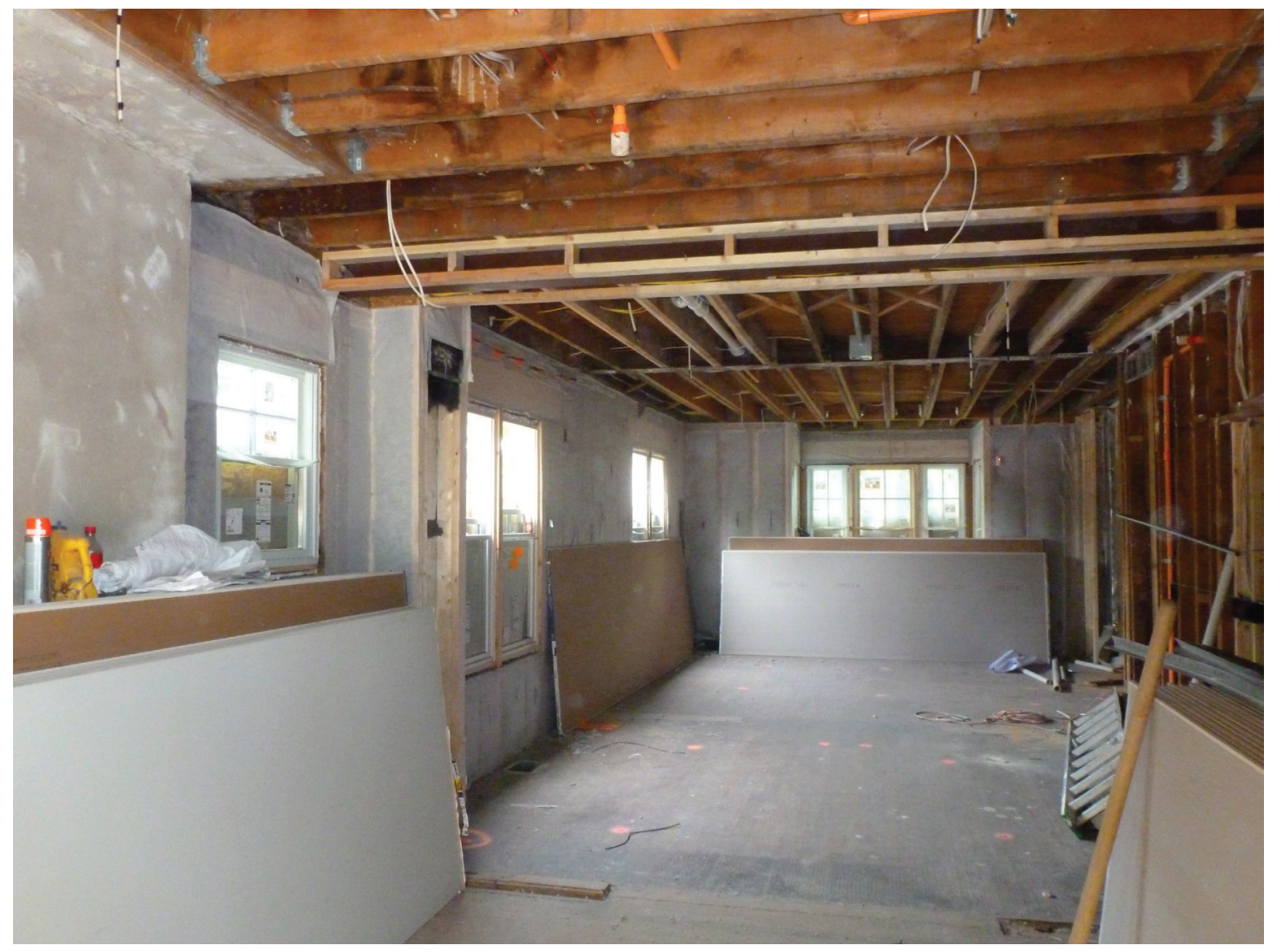

Figure 2. Gut rehab and interior insulation.

Renovation of the property required a gut rehab. The original plaster had to be removed because of its asbestos content, and reconfiguring the spaces involved removing existing interior walls. In this image, the lighter-colored wood in the roof is a support beam that allowed removal of a wall to open up the first floor classroom space. Renovating the property using LEED for Homes standards required additional insulation and energy-efficient windows. Cellulose insulation was blown into the stud spaces along the exterior walls, and new windows were installed in their original window locations, except in the rear of the classroom where a door was added. 


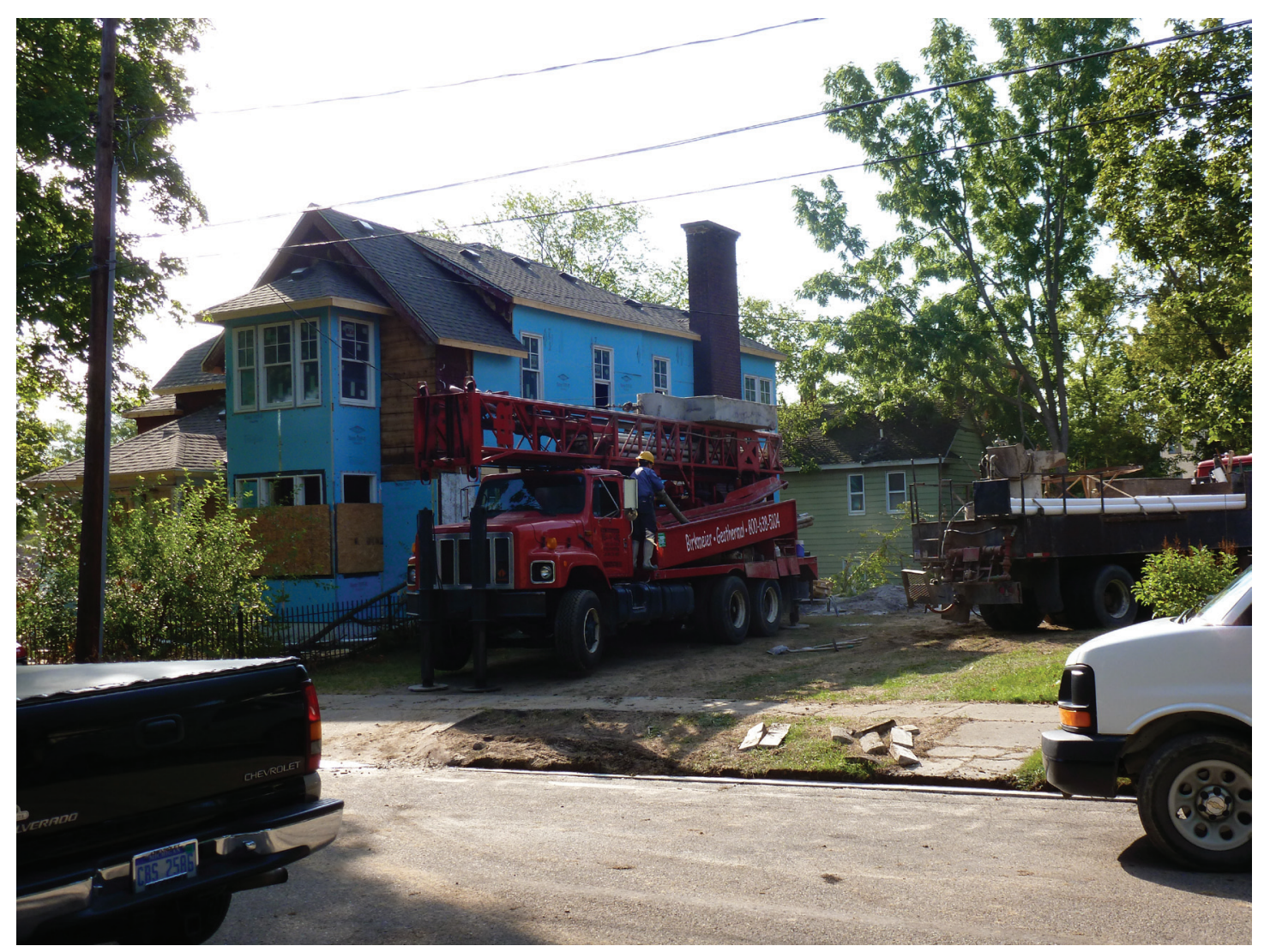

Figure 3. Exterior insulation and geothermal wells.

Because the studs were not replaced and are smaller than those used in new construction, the amount of cellulose insulation that could be installed did not meet LEED requirements. Additional rigid foam insulation was added to the exterior of the building to meet the standard. Heating and cooling are provided by a geothermal system driven by the ambient temperature of the subsurface. Seven wells were drilled to 230 feet (by the rig in the image) on the empty lot adjacent to the house, and a fluid circulating through the wells is connected to ground source heat pumps in the house basement. 


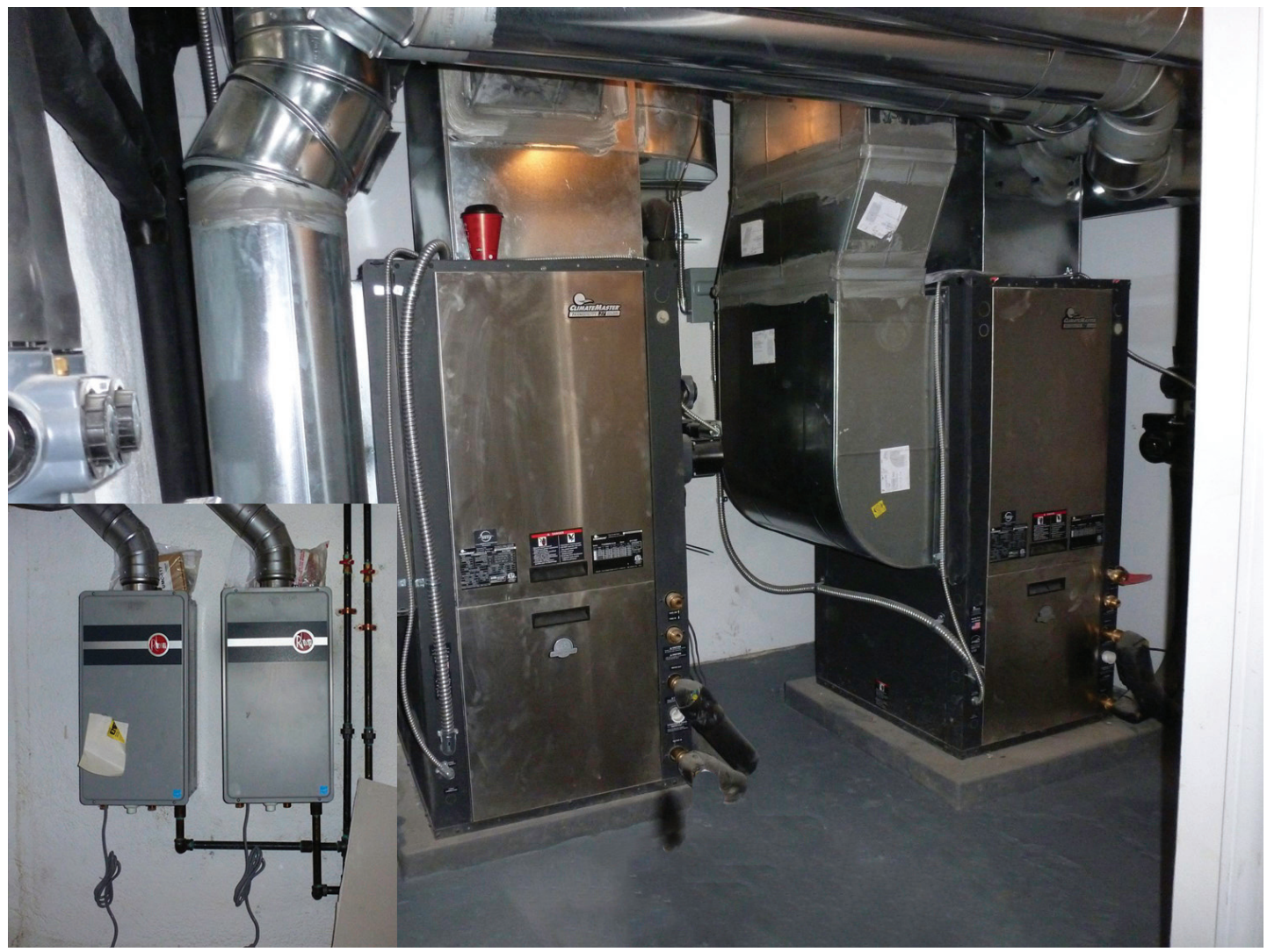

Figure 4. Heating and Cooling System

The UAH uses three water-to-air heat pumps. The first (on the right) serves the larger residential space in the house and the second unit (on the left) serves the classroom. A third unit serving the smaller residential space is out of frame. Each unit is connected to the circulating fluid which is warmer than air in the winter and cooler than air in the summer, providing the thermal energy for heating and cooling. Hot water is provided by the natural gas-driven, on-demand appliances pictured in the inset photograph. 


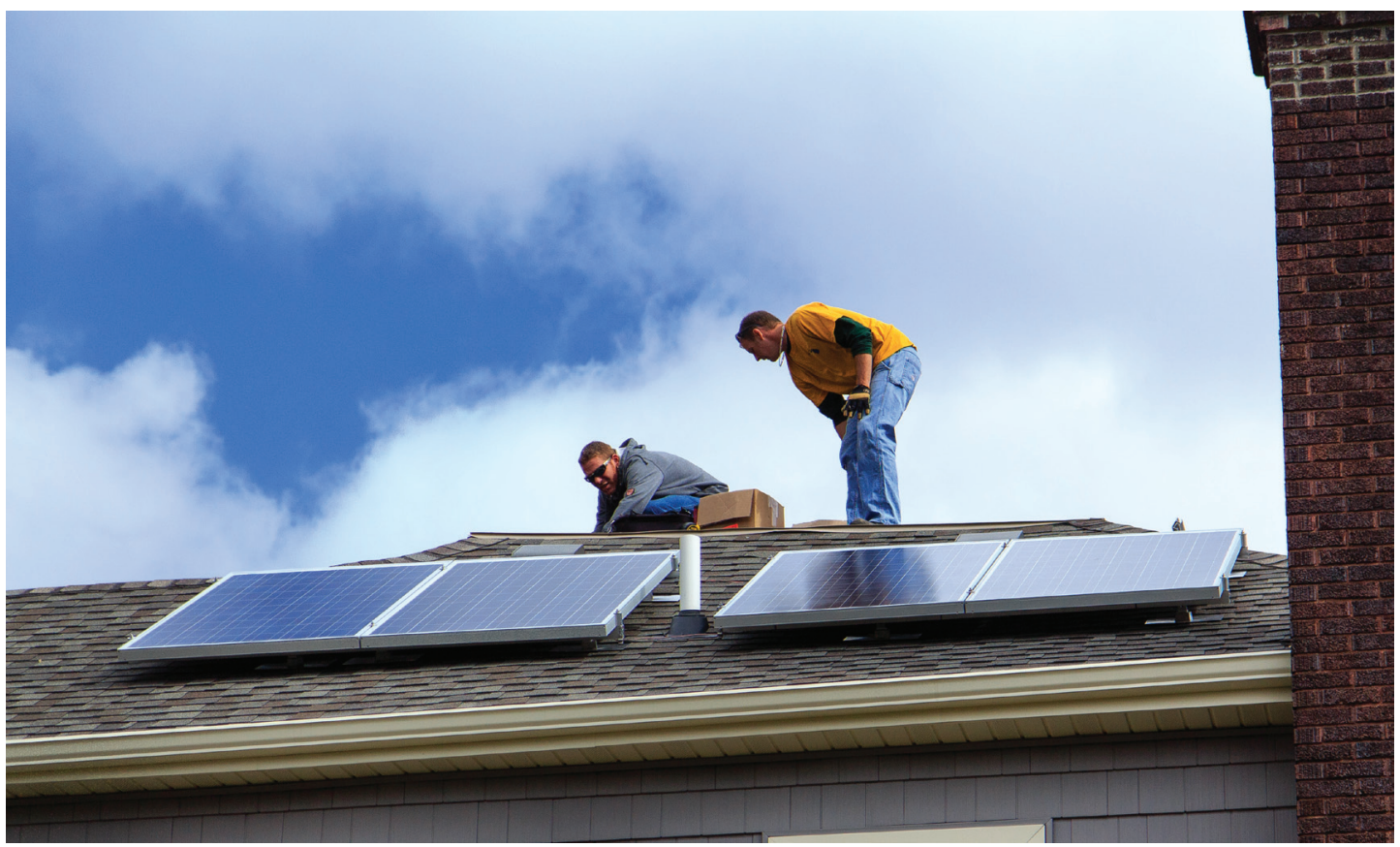

Figure 5. Solar voltaic system.

The UAH uses a $2.53 \mathrm{~kW}$-capacity solar voltaic system with 11 panels, each rated at 230 watts. The house has a north/south axis that provides an unshaded southern exposure, but the roof configuration limited the area for panel installation. Roof supports to accommodate the panels also constrained panel location. Six panels face south and four panels face west. The photograph shows the installation of the western panels. An additional panel was placed on the southern exposure facing east. Each panel has a microinverter to increase the system's efficiency and allows continuous evaluation of panel performance. 


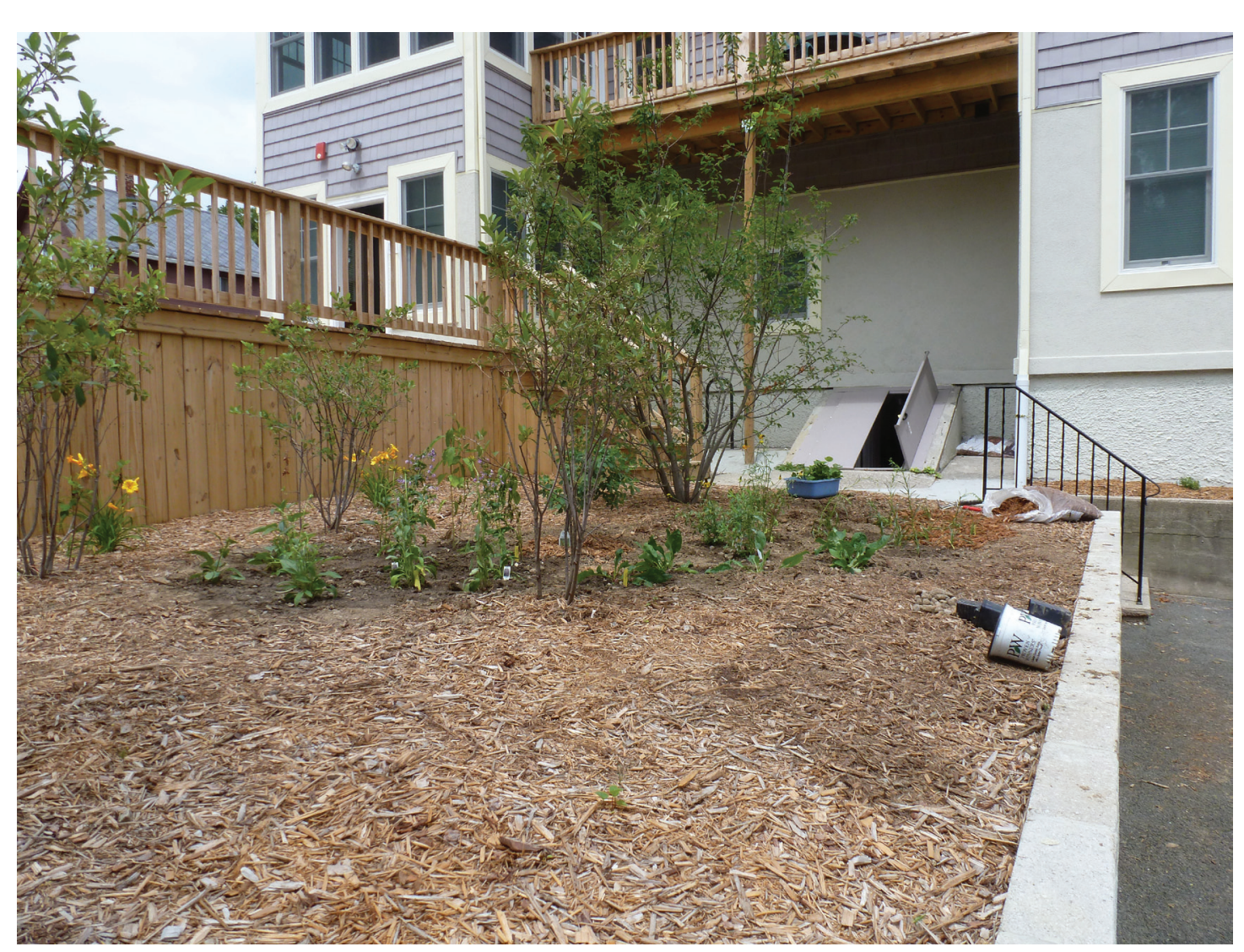

Figure 6. Stormwater Management.

Rain gardens at the front and back of the UAH help to manage stormwater and keep it on site. This image shows the rain garden on the back (south) side of the house. Rain water from most of the east-facing roof is directed into a down spout at the center of the image. It is channeled underneath the pavement and into a perforated pipe that extends into a rain garden in the foreground of the image. The soil has been modified to facilitate percolation and was planted with vegetation that can thrive in both wet and drought conditions. 


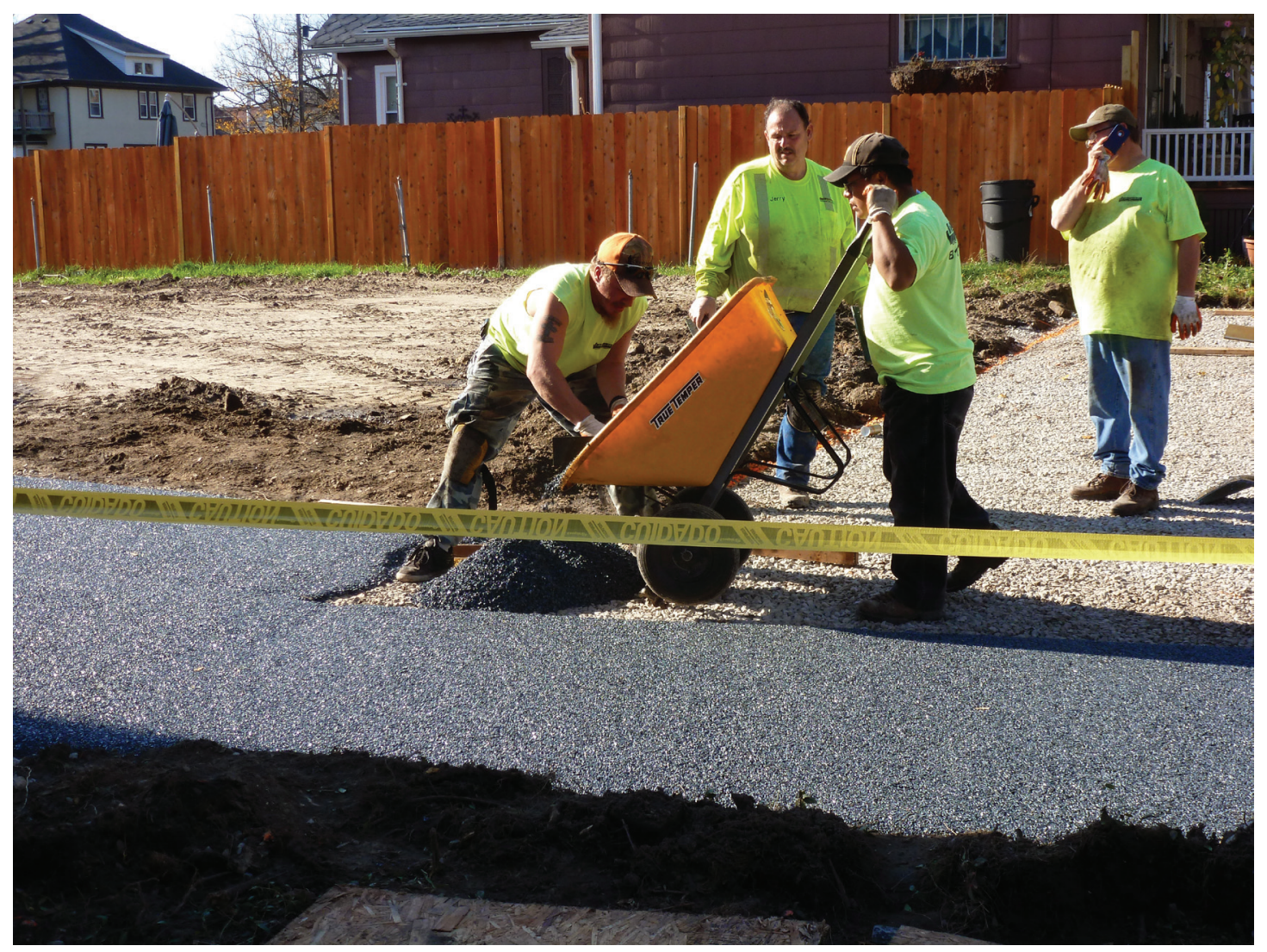

Figure 7. Porous pavement.

A second stormwater control mechanism is the porous pavement installed in the two parking areas. A pebble bed is first laid down on the site to be paved. This acts as a temporary reservoir to hold the rainwater that percolates through the pavement, allowing it to be absorbed slowly into the ground. The top layer is a mixture composed primarily of recycled tires mixed with a small amount of stone and held together with an epoxy. It is mixed on site and applied on top of the pebble bed. 


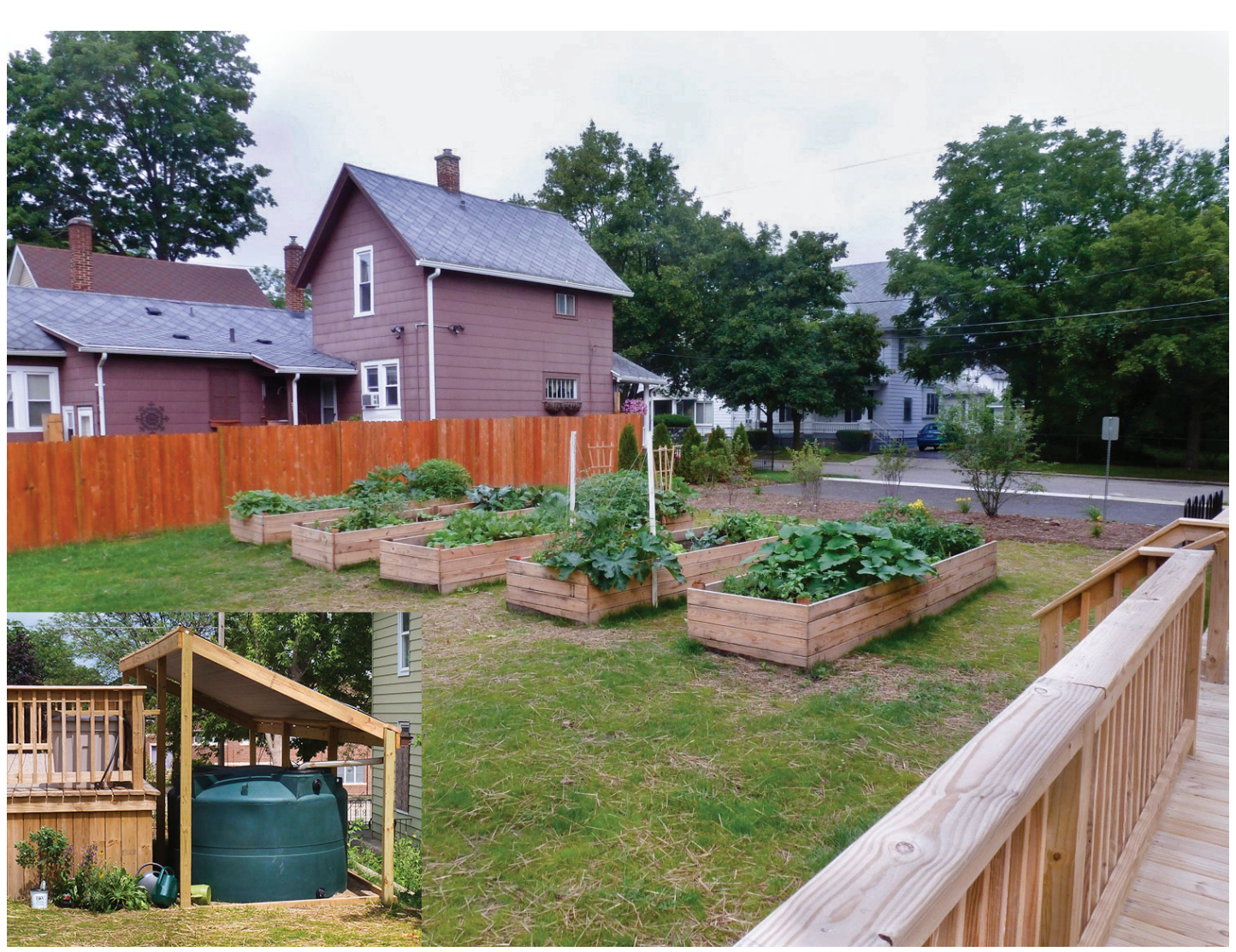

Figure 8. Food garden and rainwater harvesting

Five $16 \times 4$ foot raised beds were constructed to establish a food garden on site (the lot could not be cultivated directly because of lead contamination). Beds are made of untreated pine and are 20 inches high to accommodate the root length of common vegetables. Landscape fabric on the base of the beds allows water to drain. The gardens are cultivated by residents of the house, students, and members of the neighborhood. A water harvesting system (inset) supports the garden beds. Water from the large tank is pumped to rain barrels on the deck and gardeners access it using watering cans. 


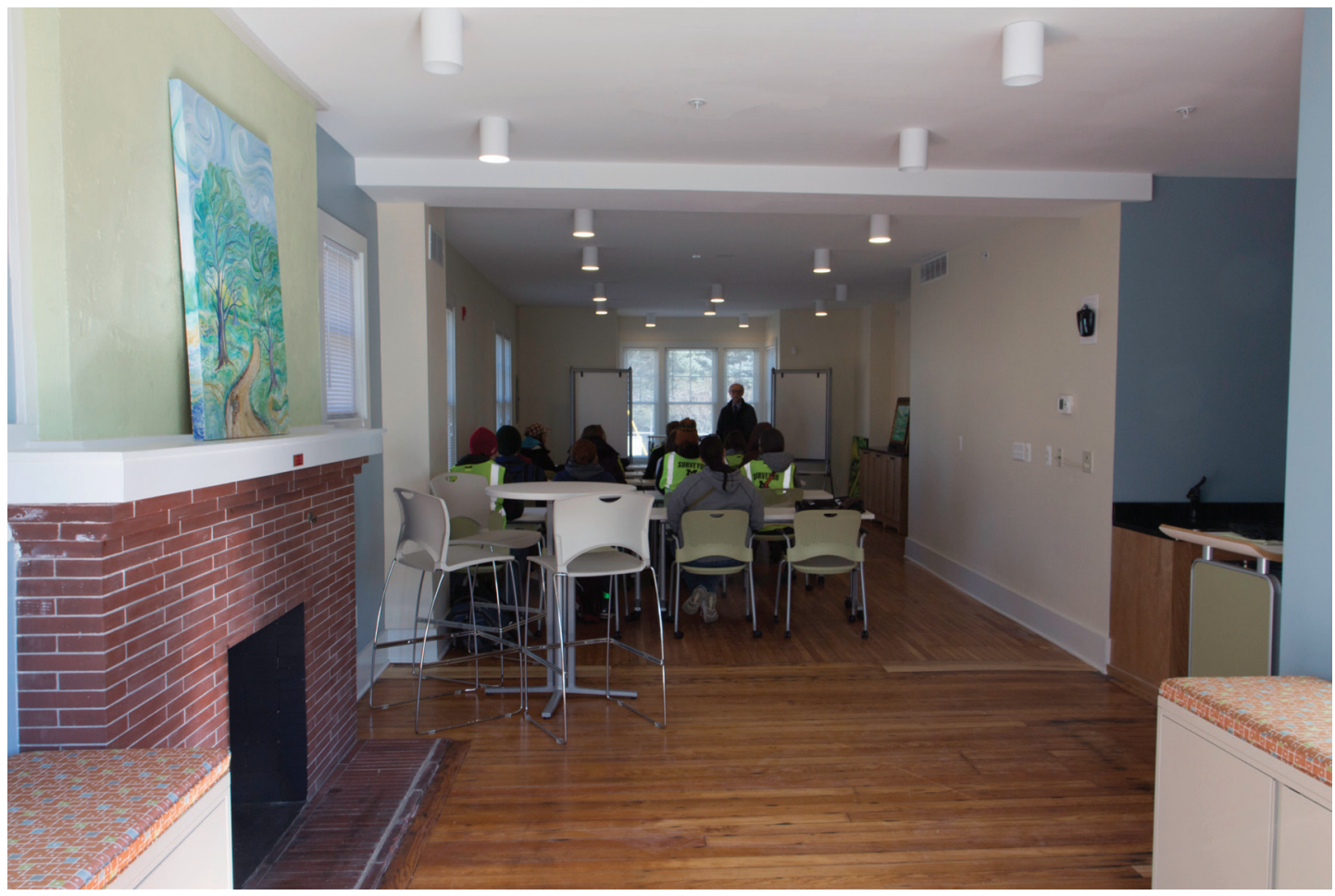

Figure 9. The UAH Classroom

The classroom was finished in the spring of 2013 and was used for presentations through fall of 2013. As of August 2014, the teaching space is being scheduled for regular classes. Data from the solar array are available online. A monitoring system tracks power use and inside temperature, as well as outside temperature, relative humidity, and solar radiation. Both of these data sets are now available for instruction and student projects. 


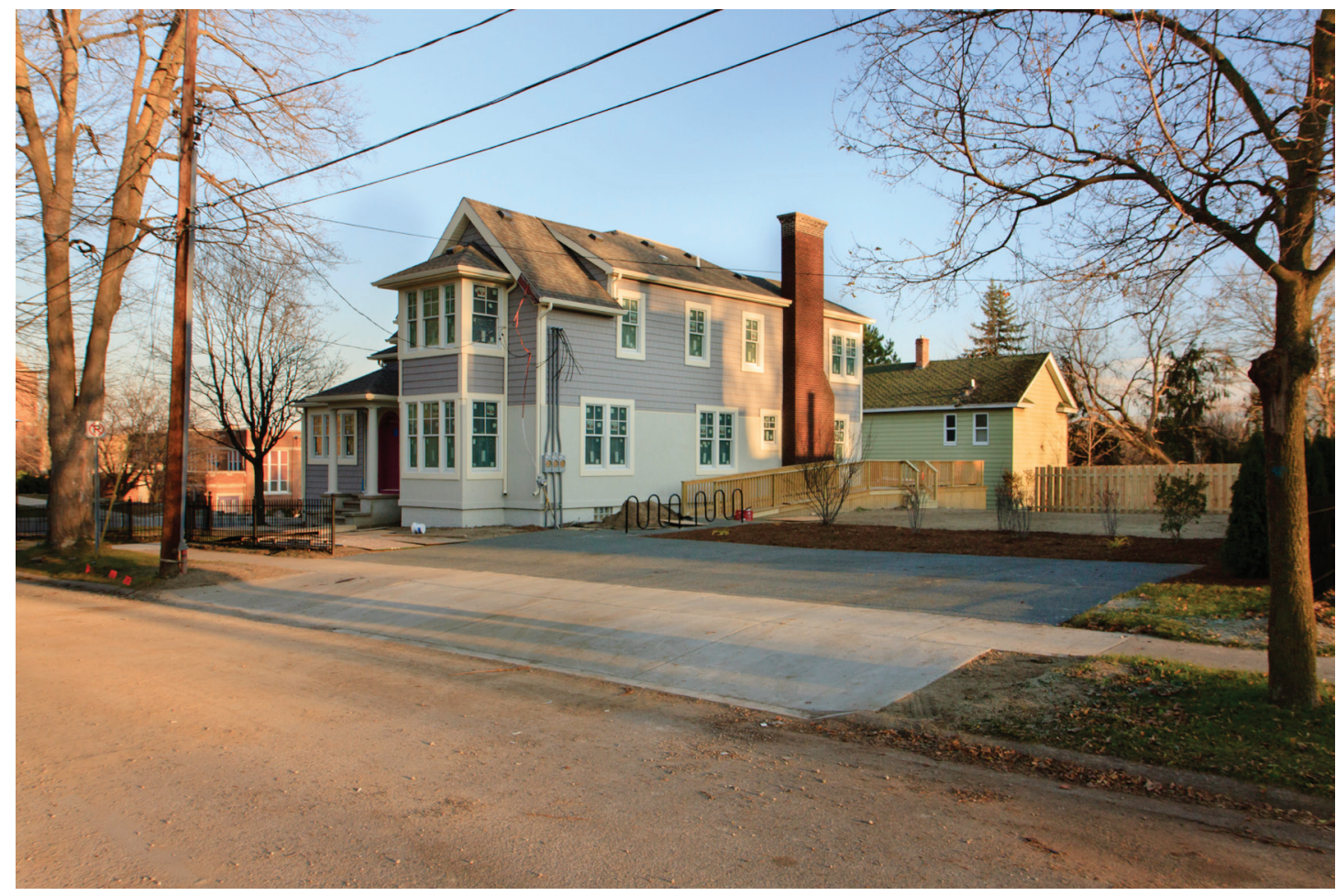

Figure 10. The completed renovation prior to occupancy

The renovation was completed at the end of 2012 and tenants moved into the residential units of the house in January 2013. LEED certification at the Platinum level was awarded in June 2014. The process involves a report on the renovation by an independent green rater who verifies a detailed checklist while work is in progress, and preparation of post renovation documentation by the project manager. This material is submitted for review to the Alliance for Environmental Sustainability (AES), which is the agent of the U.S. Green Building Council (USGBC) in Michigan. After review, and completion of any changes mandated by the AES, the submission is forwarded to USGBC for approval. 


\section{Conclusion}

The UAH was renovated using LEED standards to provide income-qualified housing and a space to support sustainability education for students and the local community, while also contributing to a more sustainable neighborhood. The partnership between the Land Bank and UM-Flint is unique in Michigan. Other universities have developed efficient buildings with alternative energy characteristics (U.S. Department of Energy 2008), but the combination of classroom and residential space in a dual use building is an innovative package.

A fundamental objective of the UAH is to demonstrate to students and the community that significant energy savings can be made by: 1) creating a tight thermal envelope for the house through insulation, 2) using a geothermal system to drive heating/cooling, 3) offsetting some of the electrical energy used in this process by installing solar panels, and 4) using on-demand water heating. A monitoring system provides continuous data on energy use, solar production, interior temperature, outside weather, and solar insolation. In effect, this monitoring system makes the whole house a laboratory in which students can evaluate the multiple variables affecting how housing structures use energy and how they contribute emissions that lead to climate change. This type of hands-on educational strategy, which is advocated by Cole (2013) and Medrick (2013), is just beginning and will feed directly into the ESS program.

The Central Park Neighborhood Association and the local Court Street Village Non-Profit Housing Corporation have been strong supporters of the UAH project. They see it as an anchor in their efforts to stabilize and sustain the neighborhood in a community with major economic and social challenges.

Central Park is also well positioned to take advantage of demographic and housing trends. Doherty and Leinberger (2010) suggest that a demographic convergence of 77 million baby boomers (those born in the U.S. between 1946 and 1964) and 76 millennials (those born in the U.S. between 1977 and 1994) is creating an increasing demand for housing in walkable urban neighborhoods. Positioned close to downtown Flint, UM-Flint, the College Cultural Center, a new center for medical training, and a relocated Flint Farmers Market, Central Park is ideally located to benefit from this trend. As a model for new residential development in a stabilized, walkable community, the UAH project will help Flint in its recovery and redevelopment.

UM-Flint now has a promising opportunity to use the building to communicate information on residential energy use and urban development to students and residents, thereby contributing to the community's better understanding of energy efficiency, sustainability, and climate change. 


\section{References}

Barth, Jon, Paul Irwin, Maria Ryen, Breanna Shell, Jonathan Tarr and Kisaki Watanabe. 2011. Flipping the Switch: Establishing the Urban Alternatives House. Ann Arbor: Urban and Regional Planning Program, University of Michigan.

Cole, L. 2013. "The Green Building as a Medium for Environmental Education." Michigan Journal of Sustainability (1) Accessed February 5, 2014. http://dx.doi.org/10.3998/ mjs.12333712.0001.012

Doherty, P. and C. Leinberger. 2010. “The Next Real Estate Boom.” Brookings. Accessed February 5, 2014. http://www.brookings.edu/articles/2010/11_real_estate_leinberger.aspx

Galbraith, Kate. 2009. "Sustainability Booms on Campus." New York Times August 19. Accessed February 5, 2014. http://www.nytimes.com/2009/08/20/education/20GREEN.html)

Metrick, R. 2013. A Pedagogy for Sustainability Education.” Journal of Sustainability Education (5) Accessed February 5, 2014. http://www.jsedimensions.org/wordpress/content/a-pedagogyfor-sustainability-education_2013_06/

U.S. Census Bureau: State and County Quick Facts. 2014. Flint (city), Michigan. Washington D.C.: U.S. Department of Commerce, Accessed April 29, 2014. http://quickfacts.census.gov/ qfd/states/26/2629000.html

U.S. Department of Energy: Energy Efficiency and Renewable Energy. 2008. Zero Energy Buildings. Washington D.C. Accessed February 5, 2014. http://zeb.buildinggreen.com/overview. cfm?projectid $=18$

U.S. Department of Housing and Urban Development (HUD). 2014. Neighborhood Stabilization Program 2. Washington D.C. Accessed February 5, 2014. http://portal.hud.gov/hudportal/ HUD?src=/program_offices/comm_planning/communitydevelopment/programs/neighborhoodspg/arrafactsheet

U.S. Environmental Protection Agency. 2013. EPA Green Buildings. Washington D.C. Accessed February 5, 2014. http://www.epa.gov/oaintrnt/projects/

U.S. Green Building Council. 2008. LEED for Homes Rating System. Accessed February 5, 2014. http://www.usgbc.org/Docs/Archive/General/Docs3638.pdf

U.S. Green Building Council. 2014. "LEED.” Accessed April 30, 2014. http://www.usgbc.org/leed

Friedhoff. A. and H. Wial. 2006. "Bearing the Brunt: Manufacturing Job Loss in the Great Lakes

Region, 1995-2005” Brookings. Accessed April 29, 2014. http://www.brookings.edu/research/ reports/2006/07/useconomics-wial 